\title{
Subtype Selective Substrates for Histone Deacetylases
}

\author{
Birgit Heltweg, ${ }^{\dagger}$ Franck Dequiedt, ${ }^{\ddagger}$ Brett L. Marshall, ${ }^{\S}$ Carsten Brauch, ${ }^{\dagger}$ Minoru Yoshida," Norikazu Nishino, ${ }^{\perp}$ \\ Eric Verdin, $§$ and Manfred J ung*, $\dagger$ \\ Department of Pharmaceutical and Medicinal Chemistry, Westfälische Wilhelms-Universität Münster, Hittorfstrasse 58-62, \\ 48149 Münster, Germany, Molecular and Cellular Biology Unit, FUSAGx, Gembl oux 5030, Bel gium, Gladstone Institute of \\ Virology and Immunology, University of California, San Francisco, California 94141-9100, Chemical Genetics Laboratory, \\ RIKEN, Hirosawa 2-1, Wako-shi, Saitama 351-0198, J apan, and Department of Applied Chemi stry, Kyushu Institute of \\ Technology, Tabata-ku, Kitakyushu-shi 804-8550, J apan
}

Received March 29, 2004

To probe the steric requirements for deacylation, we synthesized lysine-derived small molecule substrates and examined structure-reactivity relationships with various histone deacetylases. Rat liver, human HeLa, and human recombinant class I and II histone deacetylases (HDACs) as well as human recombinant $\mathrm{NAD}^{+}$-dependent SIRT1 (class III enzyme) were used in these studies. A benzyloxycarbonyl substituent on the $\alpha$-amino group yiel ded the highest conversion rates. Replacing the $\epsilon$-acetyl group with larger lipophilic acyl substituents led to a pronounced decrease in conversion by class I and II enzymes; the class III enzyme displayed a greater tolerance. Incubations with recombinant FLAG-tagged human HDACs 1, 3, and 6 showed a distinct subtype selectivity among small molecule substrates. The subtype sel ectivity of HDAC inhibitors could be predicted with these substrates and an easily obtainable mixture of HDAC subtypes.

\section{Introduction}

Histone deacetylases (HDACs) are enzymes that deacetylate histones and certain nonhistone proteins, thereby altering their conformational states or activities. ${ }^{1}$ HDACs mediate transcriptional repression, and the aberrant recruitment of deacetylase activity has been suggested as a potential molecular mechanism underlying certain types of leukemia. HDAC inhibitors usually relieve transcriptional repression and result in apoptosis or differentiation of cancer cells. Clinical studies on HDAC inhibitors as new anticancer agents are under way. ${ }^{2}$ Two classes of HDACs with 11 subtypes are zinc-dependent amidohydrolases. A third class of HDACs requires $\mathrm{NAD}^{+}$for catalysis and is not sensitive to class I and II inhibitors. ${ }^{3}$

Information on the subtype selectivity of available inhibitors is limited, and the consequences of such selectivity are unclear. No structural information on mammalian class I or II HDACs is available. However, the X-ray structure of a bacterial homologue has been resolved ${ }^{4}$ and used to construct a homology model of human HDAC1. This model showed a potential link between certain biological activities and the different binding modes of structurally similar inhibitors, thus implying subtype selectivity. ${ }^{5}$ Structure-activity studies of HDAC inhibitors may help to refine such models for other subtypes. One open question is whether the deep internal cavity "beyond" the zinc ion at the active site is also present in mammalian HDACs. Available inhibi-

\footnotetext{
* To whom corresponding should be addressed. Department of Pharmaceutical Sciences, University of Freiburg, Albertstrasse 25 79104 Freiburg, Germany. Tel: +49-761-203-4896. Fax: +49-251-2036351. E-mail: manfred.jung@pharmazie.uni-freiburg.de.

† Westfälische Wilhelms-Universität Münster.

‡ FUSAGX.

§ University of California.

"RIKEN.

${ }^{\perp}$ Kyushu Institute of Technology.
}

tors have so far failed to address this question. Structure-activity studies on tripeptide substrates for HDACs are available; however, these substrates all contain an acetyllysine group. 6,7 Thus, a probing of the region around the zinc ion using larger acyl substituents on artificial substrates seems warranted.

Previously, we introduced a small molecule substrate for HDACs, fluorescent tert-butyloxycarbonyl (Boc)-(Ac)Lys-7-amino-4-methylcoumarin (AMC) (3a), also termed MAL ${ }^{8}$ which can be used in various assay formats, such as extraction, high-performance liquid chromatography (HPLC), or plate reader ${ }^{9}$ measurements, and in a homogeneous assay. ${ }^{10} \mathrm{We}$ also introduced its benzyloxycarbonyl analogue Z-MAL (5a), a substrate for human HDACs that is also a small molecule substrate for $\mathrm{NAD}^{+}$-dependent deacetylases. ${ }^{11}$ I $\mathrm{n}$ the same study, 3a had a moderate HDAC subtype selectivity. Here, we present new analogues of $\mathbf{3 a}$ and $\mathbf{5 a}$ as probes for HDAC structure and reactivity.

\section{Results}

Synthesis. For new substrate analogues, we primarily modified the protecting group on the $\alpha$-nitrogen and the acyl substituent on the $\epsilon$-amino group. Benzyloxycarbonyl ( $\mathrm{Z}, \mathrm{Cbz}$ ) and fluorenylmethyloxycarbonyl (F moc), as well as the original Boc, were investigated as protecting groups. Because the $\alpha$-Z-anal ogue 5 a was converted faster than $\mathbf{3 a},{ }^{11}$ the $\epsilon$-acyl group was varied starting from $\mathbf{5 a}$ rather than from $\mathbf{3 a}$. The acyl groups that we studied were propionyl, butyryl, phenylacetyl, trifluoroacetyl, and also Boc in the urethanes $\mathbf{1 2 b}$ and $\mathbf{1 4}$. Compound $\mathbf{1 4}$ is a rigid lysine analogue synthesized from the racemic acid 13, which is commercially available. Additionally, the enantiomer $\mathbf{7}$ of $\mathbf{5 a}$, the $\beta$-Zanalogue $\mathbf{1 0}$, and compound $\mathbf{3 b}$ that has a trifluoromethyl instead of a methyl group on the coumarin 
<smiles>CC(=O)NCCCCC(NC(=O)OC(C)(C)C)C(=O)O</smiles><smiles>[R]c1cc(=O)oc2cc(N)ccc12</smiles>

2a: $\mathrm{R}=-\mathrm{CH}_{3}: \mathrm{AMC}$ 2b: $\mathrm{R}=-\mathrm{CF}_{3}: \mathrm{AFC}$<smiles>[R]c1cc(=O)oc2cc(NC(=O)C(CCCCNC(C)=O)NC(=O)OC(C)(C)C)ccc12</smiles><smiles>[R]C(=O)NCCCCC(NC(=O)OCc1ccccc1)C(=O)O</smiles><smiles>[R]C(=O)NCCCC[C@H](NC(=O)OCc1ccccc1)C(=O)Nc1ccc2c(C)cc(=O)oc2c1</smiles>

a: $\mathrm{R}=-\mathrm{CH}_{3}$

b: $\mathrm{R}=-\mathrm{CH}_{2} \mathrm{CH}_{3}$

c: $\mathrm{R}=-\mathrm{CH}_{2} \mathrm{CH}_{2} \mathrm{CH}_{3}$

d: $\mathrm{R}=-\mathrm{CH}_{2} \mathrm{C}_{6} \mathrm{H}_{5}$

7: enantiomer of $5 a$

e: $\mathrm{R}=-\mathrm{CF}_{3}$<smiles>CC(C)(C)OC(=O)NCCC[C@H](CC(=O)O)NC(=O)OCc1ccccc1</smiles><smiles>Cc1cc(=O)oc2cc(NC(=O)C[C@H](CCCNC(=O)OC(C)(C)C)NC(=O)OCc3ccccc3)ccc12</smiles>

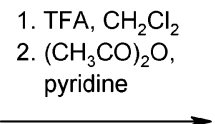<smiles>CC(=O)NCCC[C@H](CC(=O)Nc1ccc2c(C)cc(=O)oc2c1)NC(=O)OCc1ccccc1</smiles><smiles>[R]C(=O)NCCCC[C@H](NC(=O)OCC1c2ccccc2-c2ccccc21)C(=O)O</smiles>

11a,b<smiles>[R]C(=O)NCCCC[C@H](NC(=O)OCC1c2ccccc2-c2ccccc21)C(=O)Nc1ccc2c(C)cc(=O)oc2c1</smiles>

a: $\mathrm{R}=-\mathrm{CH}_{3}$

$12 a, b$

b: $R=-O^{\prime} B u$

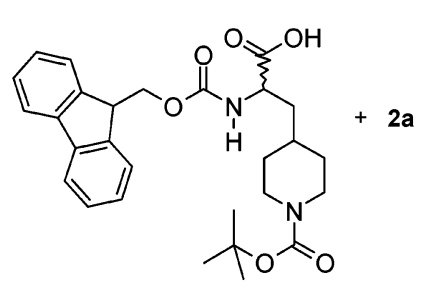

13<smiles>Cc1cc(=O)oc2cc(NC(=O)[C@H](CC3CCN(C(=O)OC(C)(C)C)CC3)NC(=O)OCC3c4ccccc4-c4ccccc43)ccc12</smiles>

14

Figure 1. Synthesis of potential HDAC substrates.

moiety were synthesized. In general, coumarin was linked to lysine derivatives with the $\mathrm{POCl}_{3} /$ pyridine activation procedure, ${ }^{12}$ as described in the original synthesis of 3a. ${ }^{8}$ Mixed anhydride coupling was used to synthesize 9 and 14. To introduce the acetyl and the trifluoroacetyl moieties, the $\epsilon$-amino group was reacted with the corresponding anhydride in pyridine. Acyl chlorides and $\mathrm{NaOH}$ were used for the other acyl substituents. ${ }^{13}$ In the synthesis of the $\beta$-analogue 10, the coumarin was coupled first to an $\epsilon$-Boc-protected $\beta$-Z-lysine and was $\epsilon$-acetylated in the last step after cleavage of the Boc group (Figure 1).
Substrate Reactivity. At a concentration of $100 \mu \mathrm{M}$, none of the substrate anal ogues (3b, 5a-e, 7, 10, 12a,b, or 14) inhibited HDAC-mediated deacetylation of $\mathbf{3 a}$, as monitored by HPLC. ${ }^{14}$ All potential substrates were incubated at the same concentrations with a rat liver HDAC preparation containing class I and II subtypes, and their conversion was quantified by HPLC. All (S)$\epsilon$-acetyl-Iysine-AMC derivatives (3a,b, 5a, and $\mathbf{1 2 a}$ ) were good substrates for rat liver HDAC; $\mathbf{5 a}$ was the best substrate (Table 1). The bulky $\alpha$-F moc derivative 12a was not converted as readily as $\mathbf{5 a}$. Similar results were obtained with $\mathbf{3 b}$ when a trifluoromethyl group 
Table 1. Conversion of Potential Substrates by Rat Liver HDAC $^{a}$

\begin{tabular}{|c|c|c|c|c|c|c|c|c|c|c|}
\hline \multirow[b]{2}{*}{ substrate } & \multicolumn{4}{|c|}{ \% conversion } & \multirow[b]{2}{*}{ substrate } & \multicolumn{5}{|c|}{$\%$ conversion } \\
\hline & $1 \mathrm{~h}$ & $2 \mathrm{~h}$ & & $24 \mathrm{~h}$ & & $\overline{1 \mathrm{~h} 2}$ & $2 \mathrm{~h}$ & $3 \mathrm{~h}$ & $6 \mathrm{~h} 2$ & \\
\hline $3 a$ & 38 & 6070 & 91 & 10 & $5 c$ & 0 & 1 & 12 & 21 & \\
\hline הוכ & 30 & $43 \quad 47$ & 68 & 9 & 50 & 0 & 0 & 0 & 0 & \\
\hline $5 a$ & 67 & 8793 & 96 & 100 & $5 e$ & 16 & 415 & 57 & 54 & \\
\hline $12 a$ & 47 & $74 \quad 78$ & 86 & 90 & 7 & 0 & 9 & 0 & 3 & 14 \\
\hline $5 b$ & 20 & $\begin{array}{ll}33 & 47\end{array}$ & 74 & 87 & & & & & & \\
\hline
\end{tabular}

${ }^{a}$ Data are from duplicate experiments.

Table 2. $I C_{50}$ Determinations for HDAC Inhibitors

\begin{tabular}{cclc}
\hline inhibitor & substrate & HDAC source & $\mathrm{IC}_{50}(\mathrm{nM})^{\mathrm{a}}$ \\
\hline $\mathbf{1 5}$ & $\mathbf{3 a}$ & rat liver & $12.0 \pm 1.2^{\mathrm{b}}$ \\
$\mathbf{1 5}$ & $\mathbf{3 b}$ & rat liver & $13.3 \pm 1.4$ \\
$\mathbf{1 5}$ & $\mathbf{5 a}$ & rat liver & $26.3 \pm 2.9$ \\
$\mathbf{1 5}$ & $\mathbf{5 a}$ & HeL $($ Geneka) & $54.5 \pm 4.0$ \\
$\mathbf{1 5}$ & $\mathbf{5 b}$ & rat liver & $20.7 \pm 2.6$ \\
$\mathbf{1 5}$ & $\mathbf{5 e}$ & rat liver & $1526 \pm 916$ \\
$\mathbf{1 5}$ & $\mathbf{1 2 a}$ & rat liver & $20.4 \pm 1.5$ \\
$\mathbf{1 6 a}$ & $\mathbf{3 a}$ & rat liver & $216 \pm 16^{\mathrm{b}}$ \\
$\mathbf{1 6 a}$ & $\mathbf{3 b}$ & rat liver & $153 \pm 40$ \\
$\mathbf{1 6 a}$ & $\mathbf{5 a}$ & rat liver & $640 \pm 33$ \\
$\mathbf{1 6 a}$ & $\mathbf{5 a}$ & HeLa (Geneka) & $1866 \pm 134$ \\
\hline
\end{tabular}

${ }^{a}$ Values are means \pm SEM of duplicate experiments. ${ }^{b}$ Data are from ref 9 .

was introduced into the coumarin ring. The $\beta$-lysine analogue $\mathbf{1 0}$ was not deacetylated by rat liver HDAC. Even after 1 day of incubation, only 14\% of enantiomer 7 of $5 \mathbf{a}$ was converted. The original substrates $\mathbf{3 a}$ and 5a were also studied using two commercially available HeLa nuclear extracts as sources of human HDAC actvity. In both cases, 5a was deacetylated to a much greater extent. ${ }^{11}$ Thus, the variations of the $\epsilon$-acyl group were performed with the $\alpha$-Z-derivative. Chain extension to propionyl in $\mathbf{5 b}$ and to butyryl in $\mathbf{5 c}$ decreased deacylation; the smaller $\mathbf{5 b}$ was the better substrate. Because only $12 \%$ of the butyramide $\mathbf{5 c}$ was converted within $3 \mathrm{~h}$, longer chains were not studied. The bulkier phenacetylamide $\mathbf{5 d}$ was not a substrate for rat liver HDAC. Surprisingly, the $\alpha-Z$ - $\epsilon$-propionylamide $\mathbf{5 b}$ was a better substrate for the HeLa nuclear extract than the $\alpha-B o c-\epsilon$-acetamide 3a (data not shown). The trifluoroacetyl derivative $\mathbf{5 e}$ was also a substrate for rat liver HDAC but was not as good as its acetyl analogue $\mathbf{5 a}$, indicating that the electron-withdrawing effect of the fluorine atoms does not increase deacetylation. The carbamates $\mathbf{1 2 b}$ and $\mathbf{1 4}$ were not deacetylated by rat liver HDAC. I $\mathrm{C}_{50}$ determinations of the inhibitors trichostatin A (TSA, 15) and MD85 (16a) revealed that $\mathbf{3 a}, \mathbf{b}, \mathbf{5 a}, \mathbf{b}$, and $\mathbf{1 2 \mathbf { a }}$ can all serve as small molecule substrates in HDAC assays (Table 2). The trifluoroacetyl derivative $\mathbf{5 e}$ behaved differently as very large concentrations of $\mathbf{1 5}$ were needed to suppress substrate cleavage. Even at $2.8 \mu \mathrm{M}$, only $66 \%$ inhibition was obtained.

Sirtuin Activity. The substrates $\mathbf{3 a} \mathbf{a} \mathbf{b}$ and $\mathbf{5 a}-\mathbf{d}$ were incubated with $8.75 \mathrm{U}$ of the human recombinant $\mathrm{NAD}^{+}$-dependent deacetylase hSIRT 1 for $16 \mathrm{~h}$ at $37^{\circ} \mathrm{C}$ (Figure 2). Several substrates were converted in ratios of about $15-45 \%$. The phenacetyl compound 5d was converted to about $25 \%$ but could not be cleaved by class I or II HDACs from rat liver (Table 1). The trifluoromethyl analogue $\mathbf{3 b}$ was also converted to a greater extent than 3a, which was not the case with rat liver HDACs. Overall, the $\alpha$-Z- $\epsilon$-acetyl anal ogue 5 a was the best substrate for all types of HDACs (see also ref 11 ).

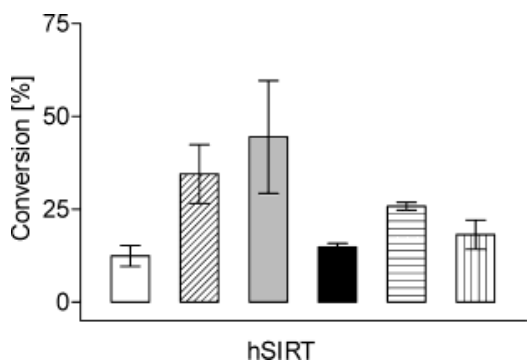

Figure 2. Conversion of substrates by recombinant human hSIRT 1. Data are from duplicate experiments. Compound 3a, clear bar; $\mathbf{3 b}$, transversally lined bar; $\mathbf{5 a}$, filled gray bar; $\mathbf{5 b}$, filled black bar; $\mathbf{5 c}$, horizontally lined bar; $\mathbf{5 d}$, vertically lined bar. The variation between $\mathbf{5 a}$ and $\mathbf{3 a}$ and between $\mathbf{5 a}$ and $\mathbf{5 b}$ is considered to be significant $(P<0.05)$.

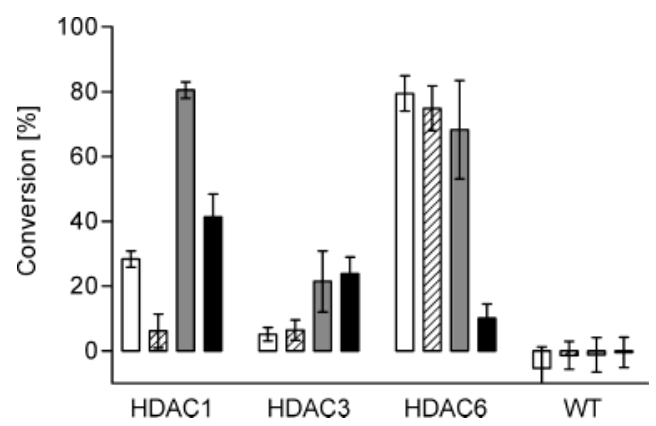

Figure 3. Conversion of substrates by immunoprecipitated human FLAG-tagged HDAC subtypes. WT: background activity with immunopreci pitation of wild-type cells. Data are from five to eleven experiments. Compound $\mathbf{3 a}$, clear bars; $\mathbf{3 b}$, lined bars; $\mathbf{5 a}$, gray bars; $\mathbf{5 b}$, black bars. For HDAC1, the variation among the means was significant for $\mathbf{3 a}$ vs $\mathbf{5 a}(P<0.001), \mathbf{3 b}$ vs $\mathbf{5 a}(P<0.001)$, $\mathbf{5 a}$ vs $\mathbf{5 b}(P<0.01)$, and $\mathbf{3 b}$ vs $\mathbf{5 b}(P<$ 0.05). For HDAC3, the variation among the means was not significant. For HDAC6, the variation among the means was significant for $\mathbf{3 a}$ vs $\mathbf{5 b}(P<0.001)$, $\mathbf{3 b}$ vs $\mathbf{5 b}(P<0.001)$, and $\mathbf{5 a}$ vs $\mathbf{5 b}(\mathrm{P}<0.001)$. F or WT, the variation among the means was not significant.

To determine if deacetylation of our lysine derivatives is mediated by hSIRT1 as observed with histones or peptidic substrates, ${ }^{15}$ we tried to detect O-acetyl ADPribose by mass spectroscopy, but the standard buffer interfered with the analysis. By using a modified Trisfree buffer, we detected O-acetyl ADP-ribose in the incubation of 5a with hSIRT1 (see Supporting I nformation). These conditions, however, did not lead to a similar detection of O-phenacetyl ADP-ribose in the incubation of $\mathbf{5 d}$. HPLC analysis of the reaction mixtures showed that the modified buffer decreased the conversion of $\mathbf{5 a}$ from $45 \%$ after $16 \mathrm{~h}$ to $10 \%$ after $19 \mathrm{~h}$ (see Supporting I nformation). No conversion of the less reactive $\mathbf{5 d}$ was observed under these conditions (data not shown).

Subtype Selectivity. Because 3 a had a moderate selectivity for HDAC6 vs HDAC1, ${ }^{11}$ we incubated the most reactive substrates with immunopreci pitated human FLAG-tagged HDACs. ${ }^{16}$ As shown in Figure 3, substrates $\mathbf{3 a}, \mathbf{b}$ and $\mathbf{5 a} \mathbf{a}, \mathbf{b}$ were converted after $3 \mathrm{~h}(5 \mathrm{~h}$ for HDAC3). Compound $3 a$ was deacetylated mostly by HDAC6 and to some extent by HDAC1, but little conversion by HDAC3 was observed even after longer incubations. When the methyl group on the coumarin ring in $\mathbf{3 b}$ was replaced with a trifluoromethyl group, reactivity was lost with HDAC1 but was retained with HDAC6. Compound 5a was deacetylated to a consider- 
<smiles>CC(/C=C/C(=O)NO)=C\C(C)C(=O)c1ccc(N(C)C)cc1</smiles><smiles>CN(CCC(=O)NO)C(=O)c1ccc(N(C)C)cc1</smiles>

16a: $n=5$

16b: $n=6$

16c: $n=7$<smiles>O=C(NO)NC1NC(=O)C(Cc2ccccc2)NC(=O)C(Cc2ccccc2)NC(=O)C(Cc2ccccc2)NC1=O</smiles>

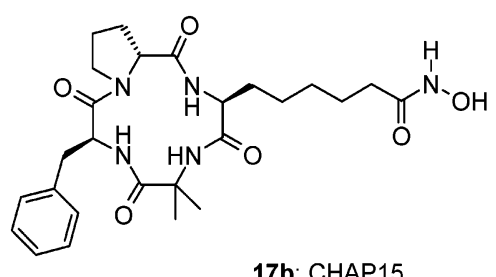

17b: CHAP15<smiles>Nc1ccccc1NC(=O)c1ccc(CNC(=O)OCc2cccnc2)cc1</smiles>

18: MS-275<smiles>CCC(C)C(NC(=O)[C@H](Cc1ccc(OC)cc1)NC(=O)C(CCCCCC(=O)NO)NC(=O)[C@H]1CCCN1)C(=O)O</smiles>

Figure 4. HDAC inhibitors.

able extent by all three subtypes, but its homol ogue $\mathbf{5 b}$ was selective for HDACl with some conversion by HDAC3. Generally, HDAC3 activity was very low, a finding confirmed by using tritium-labeled $\mathrm{H} 4$ peptide as a substrate (data not shown), and no significant preference of HDAC3 for one of the substrates was observed.

Selectivity Screening. I $\mathrm{n}$ addition to the structural information that may be gained from the reactivities, we wanted to explore whether inhibitor selectivity could be assessed by incubating a mixture of HDACs with selective substrates. This would be much easier than using immunoprecipitated subtypes and a nonselective substrate. We compared the subtype selectivities of two TSA-like inhibitors ${ }^{17}$ M 344 (16b) and M 360 (16c) and three structurally unrelated cycl otetrapeptide inhibitors (CHAPs $^{18,19}$ ) (Figure 4). M344 (16b) was selective for HDAC6 vs HDAC1 (IC 50,88 vs 249 nM). M360 (106 nM for HDACl; $165 \mathrm{nM}$ for HDAC6) (16c) and CHAPs 17a-c were all selective for HDAC1. I ncubations with the HDAC1/HDAC3 selective substrate $\mathbf{5 b}$ and the HDAC 6 selective substrate $\mathbf{3 b}$ were performed, and the results were compared with those obtained with substrate 3a, which is converted by HDAC1 and HDAC6. As shown with the homogeneous assay format, ${ }^{10}$ the HDAC6 selective inhibitor $\mathbf{1 6 b}$ had a lower $\mathrm{IC}_{50}$ with the HDAC6 selective substrate $\mathbf{3 b}$; the opposite was seen with the HDACl selective inhibitors $\mathbf{1 6 c}$ and 17a-c (Table 3).<smiles>Nc1ccccc1NC(=O)CCCCCC(=O)Nc1cccc(C2OC(CN3CCN(Cc4ccccc4)CC3)CC(c3ccc(CO)cc3)O2)c1</smiles>

19: histacin

Table 3. Inhibitor Selectivity Screening with Substrates 3a,b and $\mathbf{5 b}$

\begin{tabular}{|c|c|c|c|c|}
\hline \multirow[b]{2}{*}{ inhibitor } & \multicolumn{3}{|c|}{$I C_{50}(n M)^{a}$} & \multirow{2}{*}{$\begin{array}{c}\text { selectivity } \\
\text { (HDAC6/HDAC1) }^{b}\end{array}$} \\
\hline & $3 \mathbf{a}$ & $\mathbf{3 b}$ & $5 b$ & \\
\hline $16 b$ & $78.2 \pm 8.3$ & $148 \pm 14$ & $3512 \pm 999$ & 0.35 \\
\hline $16 c$ & $256 \pm 23$ & $488 \pm 165$ & $241 \pm 34$ & 1.6 \\
\hline $17 a$ & $349 \pm 79$ & $411 \pm 20$ & $65.6 \pm 8.4$ & 10 \\
\hline $17 b$ & $137 \pm 13$ & $226 \pm 16$ & $21.2 \pm 3.4$ & 86 \\
\hline $17 \mathrm{c}$ & $55.7 \pm 7.6$ & $80.4 \pm 11.9$ & $6.29 \pm 1.02$ & 34 \\
\hline
\end{tabular}

a Values are means \pm SEM of duplicate experiments. ${ }^{b}$ Calculated by dividing the $I_{50}$ values on the immunoprecipitated human enzymes using radioactively label ed histone peptides as a substrate.

\section{Discussion}

Structure-reactivity studies on a set of synthetic nonpeptidic HDAC substrates showed that conversion rates and subtype selectivity are dependent on the structure of the substrate. The $\epsilon$-acetyl-(S)-lysines were good substrates. $\beta$-Lysine derivative $\mathbf{1 0}$ and (R)-Iysine derivative 7 were poor substrates but did not inhibit the enzyme. Thus, the region of the enzyme that takes up the lysine side chain is quite restricted to potential branched chain substrates or inhibitors. Variations of the $\alpha$-protecting groups were less critical for substrate acceptance by rat liver HDAC. HDACl seems to contain a structural element distant from the zinc ion that can distinguish between a methyl (in 3a) and a trifluoromethyl (in 3b) substituent on the coumarin ring. This element is not present in HDAC6, which converts both 
substrates to the same extent. A chain extension of the $\epsilon$-acyl substituent is possible, but the butyrate $\mathbf{5 c}$ is converted to a significant extent only within 1 day. Increased lipophilic bulk, as in a phenylacetyl derivative $\mathbf{5 d}$ or in $\epsilon$-tert-butylcarbamates, abol ished the ability to serve as an HDAC substrate. These compounds are not inhibitors, so we assume that they cannot access the active site. Of course, the carbamates also have a chemical reactivity that is different from that of the amides. An $\epsilon$-trifluoroacetyl group in $\mathbf{5 e}$ also leads to an HDAC substrate, but its conversion cannot be inhibited completely with TSA at standard concentrations (15). The reason for this is unclear. The propionyl lysine $\mathbf{5 b}$ was selective for HDAC1 and HDAC3, suggesting that those enzymes have a slightly bigger cavity around the zinc ion than HDAC6.

The information from these experiments may be used to refine homology models for HDAC subtypes. Such models are the sole source of structural information for the rational design of new selective inhibitors of this therapeutically interesting class of potential drugs. Concerning the existence of a remote internal cavity in mammalian HDACs, our systematic studies support the hypothesis that a large cavity is not present, raising doubt about designing inhibitors that target to protein regions beyond the zinc ion. However, results from a docking study performed on the bacterial HDLP led the authors to the opposite conclusion. ${ }^{20}$

The X-ray structure of human HDAC8 (Somoza, J . R.; Skene, R. J .; Katz, B. A.; Mol, C.; Ho, J. D. et al. Structural snapshots of human HDAC8 provide insights into the class I histone deacetylases. Structure (Camb) 2004, 12, 1325-1334) was published while our manuscript was in press. According to this work a large internal cavity is indeed not present in human class I enzymes as suggested by our work. Our results shed light on the ongoing discussion ${ }^{21}$ about the mode of action of HDAC inhibitors that contain a phenylenediamine amide group, such as MS-275 (18), ${ }^{22-24}$ histacin (19), ${ }^{25}$ and others. ${ }^{26}$ Although in vitro enzyme inhibition by MS275 in the low micromolar range has been reported, ${ }^{24}$ we could not reproduce such an inhibition using our small molecule substrate or the commercially available Biomol assay (data not shown). Recently, using labeled histone and FLAG-tagged HDAC subtypes, another group reported in vitro inhibition around $100 \mu \mathrm{M} ; 27$ we and others found cellular activity at submicromolar concentrations. ${ }^{22}$ While attack on the zinc ion at the active site is still possible and might be stabilized by hydrogen bonding, which is unfavorable for our butyramide or phenacetyl amides, it is feasible that MS-275 and similar compounds bind at a different site (e.g., with a consecutive allosteric modulation ${ }^{21}$ ) which depends on certain cofactors.

In the published X-ray structure of HDAC8 with the inhibitor TSA a second molecule TSA is bound closely to the active site and maybe binding of an inhibitor to this second binding site alone might result in HDAC inhibition. Nevertheless, our conclusions drawn from the longer acyl chain substrates must be viewed with some caution.

Several of our substrate analogues, among them the phenylacetyl derivative 5d, which was not deacylated by class I or II enzymes, are substrates for a member of the newly discovered $\mathrm{NAD}^{+}$-dependent family of HDACs. The sirtuin hSIRT1, which uses NAD ${ }^{+}$to take up the acyl group, has a wider range of acceptable substrates. The same should be true for potential inhibitors. U sing mass spectrometry, we could show for the $\epsilon$-acetyl derivative $\mathbf{5 a}$ that O-acetyl ADP-ribose is formed with these small molecule substrates as a consequence of the acyl transfer.

Finally, the use of the new subtype selective substrates makes it possible to predict subtype sel ectivity of HDAC inhibitors, at least semiquantitatively. With further refinement, this approach could eliminate or reduce the need to use immunoprecipitated HDAC subtypes, simplifying lead discovery in that promising class of compounds. HDAC 6 has two catalytic domains, one for histone deacetylation and one for tubulin deacetylation. ${ }^{28}$ We do not know whether both domains contribute to the conversion of our lysine coumarin derivatives, but we propose that this is the case. Concerning our HDAC inhibitors, we assume that these compounds inhibit both catalytic domains of HDAC 6 in the same way as structurally similar inhibitors. ${ }^{25}$ These assumptions are due to the absence of structural elements that favor binding to the tubulin deacetylase domain as well as to the absence of an ortho-aminobenzamide element (favoring binding to the HDAC domain). The HDAC6 selective M344 (16b) is a good inducer of terminal cell differentiation in Friend leukemia cells ${ }^{17}$ and of $\gamma$-globin expression in a promotor assay and in human erythroid cell cultures. ${ }^{29}$ Its more HDAC 1 selective homologue M360 (16c) mainly exerts an antiproliferative activity in these assays. These findings warrant further investigation of HDAC inhibitor subtype selectivity with respect to biological activity. The predictive power of our subtype sel ective substrates for such activities will be part of the investigations in that direction.

\section{Conclusion}

We used substrate anal ogues to assess the structural requirements for compounds that access the catalytic site of HDAC. For the region surrounding the zinc ion, little variation seems to be possible for class I and II HDACs, at least for lipophilic substituents. Fewer restrictions were found with a member of the class III family. These results demonstrate the potential for developing bisubstrate sirtuin inhibitors. New subtype selective substrates should be useful for refining homology models of human HDACs; in the absence of structural data, such models are important tools for rational drug design. These substrates will also al low inhibitors to be tested for subtype sel ectivity with easily obtainable extracts containing mixtures of different HDACs.

\section{Experimental Section}

Melting points are uncorrected. Elemental analysis was performed on a Perkin-E Imer CHN-Analyzer. I R spectra were recorded on a Shimadzu 470 in $\mathrm{KBr}$. Wavenumbers are listed in $\mathrm{cm}^{-1}$. ${ }^{1} \mathrm{H}$ nuclear magnetic resonance (NMR) was done on a Varian Mercury-400BB (400.3 M Hz), and ${ }^{13} \mathrm{C}$ NMR was done on the same instrument (100.7 MHz). MS spectrometry for compound identification was done on a Finnigan MAT 312 (EI). Detection of O-acetyl ADP-ribose by MS spectrometry was performed by ESI on a Waters-Micromass Quattro LCZ equipped with a nanospray inlet. Flash chromatography was performed with silica gel 60, 230-400 mesh (Merck). Pyridine 
and tetrahydrofuran were dried over molecular sieves ( $3 \AA$ ). Fluorescence spectra were recorded on a Shimadzu RF-540. A Shimadzu RF 535 was used as the fluorescence detector for HPLC and a LiChrosorb RP $185 \mu \mathrm{m}$ column $(125 \mathrm{~mm} \times 3$ $\mathrm{mm}, \mathrm{Knauer})$ or a Luna $5 \mu \mathrm{m}$ Phenylhexyl column $(250 \mathrm{~mm}$ $\times 4.6 \mathrm{~mm}$, Phenomenex) was used in the assay. For purity testing of compounds by HPLC, a Kontron 335 UV detector $(254 \mathrm{~nm})$ was used with the same two columns. TSA (15) was from Sigma. Lysine derivatives were from Bachem. Other chemicals were from Fluka and Aldrich. Compounds $\mathbf{3 a}, 8,30$ $\mathbf{5 a},{ }^{11} \mathbf{1 6} \mathbf{a}-\mathbf{c}, 17,31,32$ and $\mathbf{1 7 a}-\mathbf{c}^{19}$ were prepared as described. HeLa nuclear extracts were from Geneka (200 $\mu \mathrm{g} / 40 \mu \mathrm{L}$, catal og no. 100200) and U pstate (50 $\mu \mathrm{g} / 25 \mu \mathrm{L}$, catalog no. 12309). hSIRT1 was from Biomol (catalog no. SE-239).

Synthesis. Method A. Amide Formation with Acyl Chlorides. To an ice-col d solution of $\mathrm{N}$ - $\alpha$-benzyl oxycarbonylL-lysine (Z-Lys) in $1 \mathrm{M} \mathrm{NaOH}$ ( $1 \mathrm{mmol} / \mathrm{mmol}$ lysine) and $\mathrm{H}_{2} \mathrm{O}$ ( $8 \mathrm{~mL} / \mathrm{mmol}$ lysine), the acyl chloride (1 equiv) in anhydrous tetrahydrofuran ( $1 \mathrm{~mL} / \mathrm{mmol}$ acid chloride) and $1 \mathrm{M} \mathrm{NaOH} \mathrm{(1}$ $\mathrm{mmol} / \mathrm{mmol}$ lysine) were separately added dropwise with stirring over $20 \mathrm{~min}$. The reaction mixture was saturated with $\mathrm{NaCl}$, cooled below $0{ }^{\circ} \mathrm{C}$, and acidified to $\mathrm{pH} 1$ with $2 \mathrm{M} \mathrm{HCl}$. The product was extracted with ethyl acetate, and the combined organic layers were extracted with $5 \% \mathrm{NaHCO}_{3}$ solution. The bicarbonate solution was acidified and extracted three times with ethyl acetate. The combined organic extracts were washed with saturated brine and dried over $\mathrm{Na}_{2} \mathrm{SO}_{4}$, and the solvent was evaporated.

Method B. Amide Formation with Anhydrides. The amine and acetic anhydride were dissolved in equimolar amounts in dry pyridine. After stirring at room temperature for 1 day, the mixture was acidified to $\mathrm{pH} 1$ with $2 \mathrm{M} \mathrm{HCl}$. The product was extracted three times with ethyl acetate, and the combined organic layers were extracted with $5 \% \mathrm{NaHCO}_{3}$. The bicarbonate solution was acidified and extracted three times with ethyl acetate. The combined organic extracts were washed with saturated brine and dried over $\mathrm{Na}_{2} \mathrm{SO}_{4}$, and the solvent was evaporated.

Method C. Amide Formation with Phosphoryl Chloride. The acid was mixed with equivalent amounts of $A M C$ (2a) in dry pyridine $(6 \mathrm{~mL} / \mathrm{mmol})$ at $-15{ }^{\circ} \mathrm{C}$. Phosphoryl chloride $(0.25 \mathrm{~mL} / \mathrm{mmol})$ was then added by syringe, resulting in a orange-red solution. The mixture was stirred for $1 \mathrm{~h}$ at $-15^{\circ} \mathrm{C}$, poured into a 10 -fold volume of ice $/ \mathrm{H}_{2} \mathrm{O}$, and extracted three times with $50 \mathrm{~mL}$ of ethyl acetate. The combined organic phase was washed consecutively with $\mathrm{H}_{2} \mathrm{O}, 2 \mathrm{M} \mathrm{HCl}, \mathrm{H}_{2} \mathrm{O}, 5 \%$ $\mathrm{NaHCO}_{3}, \mathrm{H}_{2} \mathrm{O}$, and saturated brine (50 $\mathrm{mL}$ each). The organic layer was dried over $\mathrm{Na}_{2} \mathrm{SO}_{4}$, and the sol vent was evaporated.

Method D. Amide Formation with Mixed Anhydride. To a solution of the acid in tetrahydrofuran $(10 \mathrm{~mL} / \mathrm{mmol})$ was added N-methyl-morpholine (NMM, 1 equiv) under nitrogen, and the solution was stirred for $5 \mathrm{~min}$. The solution was cooled to $-15^{\circ} \mathrm{C}$ and stirred for another $5 \mathrm{~min}$. I sobutyl chlor oformate (1 equiv) was added dropwise, and the mixture was stirred for 10 min. AMC ( $2 a$ ) (1 equiv) and NMM (2 equiv) were added, and the suspension was stirred for $15 \mathrm{~min}$ at $-15^{\circ} \mathrm{C}$ and for $2 \mathrm{~h}$ at room temperature. The mixture was then poured into $50 \mathrm{~mL}$ of $2 \mathrm{M} \mathrm{HCl}$ solution and extracted three times with 50 $\mathrm{mL}$ of ethyl acetate. The combined organic phases were washed consecutively with $\mathrm{H}_{2} \mathrm{O}, 2 \mathrm{M} \mathrm{HCl}, \mathrm{H}_{2} \mathrm{O}, 5 \% \mathrm{NaHCO}_{3}, \mathrm{H}_{2} \mathrm{O}(50$ $\mathrm{mL}$ ), and saturated brine. The organic layer was dried over $\mathrm{Na}_{2} \mathrm{SO}_{4}$, and the solvent was evaporated.

(S)-[5-Acetylamino-1-(2-oxo-4-trifluoromethyl-2Hchromen-7-ylcarbamoyl)pentyl]carbamic Acid tert-Butyl Ester (3b). Compound 3b was synthesized by method C from $\mathrm{N}-\alpha$-(Boc)- $\mathrm{N}-\epsilon$-acetyl-lysine (1) $(0.30 \mathrm{~g}, 1.04 \mathrm{mmol})$, 7-amino-4-trifluoro-methylcoumarin (AFC, 2b) $(0.24 \mathrm{~g}, 1.04$ $\mathrm{mmol})$, and $\mathrm{POCl}_{3}(0.25 \mathrm{~mL})$. The resulting product was chromatographed with ethyl acetate/methanol (20:1). Yield: $0.28 \mathrm{~g}$ (54\%); mp $121{ }^{\circ} \mathrm{C}$. IR: 3346, 1734, 1704, 1619, 1580, 1526. ${ }^{1} \mathrm{H}$ NMR (DMSO-d 6 ): $\delta 10.58(\mathrm{~s}, 1 \mathrm{H}), 7.90\left(\mathrm{~d}, 1 \mathrm{H},{ }^{4} \mathrm{~J}=\right.$ $1.70 \mathrm{~Hz}), 7.80(\mathrm{t}, 1 \mathrm{H}, 3 \mathrm{~J}=5.29 \mathrm{~Hz}), 7.68(\mathrm{~d}, 1 \mathrm{H}, 3 \mathrm{~J}=7.36)$, $7.54(\mathrm{dd}, 1 \mathrm{H}, 3 \mathrm{~J}=8.87 \mathrm{~Hz}, 4 \mathrm{~J}=1.70 \mathrm{~Hz}), 7.16(\mathrm{~d}, 1 \mathrm{H}, 3 \mathrm{~J}=$ 7.36), $6.90(\mathrm{~s}, 1 \mathrm{H}), 4.05-4.02(\mathrm{~m}, 1 \mathrm{H}), 3.00(\mathrm{~d}, 2 \mathrm{H}, 3 \mathrm{~J}=5.48$
$\mathrm{Hz}), 1.75(\mathrm{~s}, 3 \mathrm{H}), 1.61-1.23(\mathrm{~m}, 15 \mathrm{H}) .{ }^{13} \mathrm{C}$ NMR (DMSO- $\left.\mathrm{d}_{6}\right)$ : $\delta$ 172.61, 168.90, 158.62, 155.60, 154.73, 143.26, 139.18 (q, ' ${ }^{2}$ c,F $=32.03 \mathrm{~Hz}), 125.45,121.69\left(\mathrm{q},{ }^{1} \mathrm{~J}, \mathrm{~F}=275.4 \mathrm{~Hz}\right), 116.07$, 114.36, 108.25, 106.23, 78.19, 55.35, 40.36, 31.17, 28.87, 28.18, 23.14, 22.60. MS (EI): m/z 243 (35), 126 (100), 84 (97). Anal. $\left(\mathrm{C}_{23} \mathrm{~F}_{3} \mathrm{H}_{28} \mathrm{~N}_{3} \mathrm{O}_{6}\right) \mathrm{C}, \mathrm{H}, \mathrm{N}$.

(S)-2-Benzyloxycarbonylamino-6-propionylamino-hexanoic Acid (4b). Compound $\mathbf{4 b}$ was synthesized by method A from Z-Lys $(2.8 \mathrm{~g}, 10 \mathrm{mmol})$ and propionyl chloride $(0.87$ $\mathrm{mL}, 10 \mathrm{mmol})$. Yield: $0.89 \mathrm{~g}(26 \%)$, viscous oil.

(S)-2-Benzyloxycarbonylamino-6-butyrylamino-hexanoic Acid (4c). Compound $\mathbf{4 c}$ was synthesized by method A from Z-Lys $(2.8 \mathrm{~g}, 10 \mathrm{mmol})$ and butyryl chloride $(1.05 \mathrm{~mL}$, $10 \mathrm{mmol}$ ). Yield: $0.34 \mathrm{~g}(10 \%)$, viscous oil.

(S)-2-Benzyloxycarbonylamino-6-phenylacetylaminohexanoic Acid (4d). Compound $\mathbf{4 d}$ was synthesized by method A from Z-Lys $(2.2 \mathrm{~g}, 7.85 \mathrm{mmol})$ and phenylacetyl chloride (1.04 $\mathrm{mL}, 7.85 \mathrm{mmol})$. The resulting product was chromatographed with ethyl acetate/n-hexane/acetic acid (2: 1:0.03). Yield: $1.97 \mathrm{~g}(63 \%)$, viscous oil.

(S)-2-Benzyloxycarbonylamino-6-(2,2,2-trifluoroacetylamino)hexanoic Acid (4e). Compound 4 e was synthesized by method B from Z-Lys $(2.2 \mathrm{~g}, 7.85 \mathrm{mmol})$ and trifluoroacetic anhydride ( $1.11 \mathrm{~mL}, 7.85 \mathrm{mmol})$. Yield: $0.78 \mathrm{~g}(26 \%)$, viscous oil.

(S)-[1-(4-Methyl-2-oxo-2H-chromen-7-ylcarbamoyl)-5propionylamino-pentyl]carbamic Acid Benzyl Ester (5b). Compound $\mathbf{5 b}$ was synthesized by method $\mathrm{C}$ from $\mathbf{4 b}(0.67 \mathrm{~g}$, $2 \mathrm{mmol}), 2 \mathrm{a}(0.35 \mathrm{~g}, 2 \mathrm{mmol})$, and $\mathrm{POCl}_{3}(0.4 \mathrm{~mL})$. The resulting product was chromatographed with ethyl acetate. Yield: $0.44 \mathrm{~g}(45 \%) ; \mathrm{mp} 161{ }^{\circ} \mathrm{C}$. IR: 3313, 2939, 1695, 1620, $1585,1526 .{ }^{1} \mathrm{H}$ NMR (DMSO-d 6 ): $\delta 10.47(\mathrm{~s}, 1 \mathrm{H}), 7.76-7.34$ $(\mathrm{m}, 10 \mathrm{H}), 6.25(\mathrm{~s}, 1 \mathrm{H}), 5.02(\mathrm{~s}, 2 \mathrm{H}), 4.18-4.00(\mathrm{~m}, 1 \mathrm{H}), 3.00$ $(\mathrm{m}, 2 \mathrm{H}), 2.39(\mathrm{~s}, 3 \mathrm{H}), 2.01(\mathrm{q}, 2 \mathrm{H}, 3 \mathrm{~J}=7.62 \mathrm{~Hz}), 1.74-1.52$ $(\mathrm{m}, 2 \mathrm{H}), 1.47-1.19-(\mathrm{m}, 4 \mathrm{H}), 0.94\left(\mathrm{t}, 3 \mathrm{H},{ }^{3} \mathrm{~J}=7.62 \mathrm{~Hz}\right) .{ }^{13} \mathrm{C}$ NMR $\left(\mathrm{CDCl}_{3}\right): \delta 172.34,171.71,159.76,155.89,153.38$, $152.86,142.00,136.71,128.15$ (2C), 127.64, 127.57 (2C), $125.77,115.06,114.89,112.15,105.51,65.43,55.55,38.17$, 31.33, 28.92, 28.55, 23.13, 18.05, 10.09. MS (EI): $\mathrm{m} / \mathrm{z} 447$ (10), 107 (21), 91 (60), 79 (100). Anal. $\left(\mathrm{C}_{27} \mathrm{H}_{31} \mathrm{~N}_{3} \mathrm{O}_{6}\right) \mathrm{C}, \mathrm{H}, \mathrm{N}$.

(S)-[5-B utyrylamino-1-(4-methyl-2-oxo-2H-chromen-7ylcarbamoyl)pentyl]carbamic Acid Benzyl Ester (5c). Compound $5 \mathrm{c}$ was synthesized by method $\mathrm{C}$ from $4 \mathrm{c}(0.27 \mathrm{~g}$, $0.77 \mathrm{mmol}), 2 \mathrm{a}(0.14 \mathrm{~g}, 0.77 \mathrm{mmol})$, and $\mathrm{POCl}_{3}(0.15 \mathrm{~mL})$. The resulting product was chromatographed with ethyl acetate/nhexane (2:1). Yield: $0.15 \mathrm{~g}(38 \%) ; \mathrm{mp} 156^{\circ} \mathrm{C}$. IR: 3306, 3091, $2960,1688,1619,1584,1529 .{ }^{1} \mathrm{H}$ NMR (DMSO-d $\left.\mathrm{d}_{6}\right): \delta 10.47$ $(\mathrm{s}, 1 \mathrm{H}), 7.76-7.29(\mathrm{~m}, 10 \mathrm{H}), 6.25(\mathrm{~s}, 1 \mathrm{H}), 5.01(\mathrm{~s}, 2 \mathrm{H}), 4.18-$ $4.00(\mathrm{~m}, 1 \mathrm{H}), 3.00(\mathrm{~m}, 2 \mathrm{H}), 2.39(\mathrm{~s}, 3 \mathrm{H}), 1.96(\mathrm{q}, 2 \mathrm{H}, 3 \mathrm{~J}=7.42$ $\mathrm{Hz}), 1.65-1.62(\mathrm{~m}, 2 \mathrm{H}), 1.47-1.37(\mathrm{~m}, 6 \mathrm{H}), 0.78(\mathrm{t}, 3 \mathrm{H}, 3 \mathrm{~J}=$ $7.42 \mathrm{~Hz}$ ). ${ }^{13} \mathrm{C}$ NMR (DMSO-d $\left.\mathrm{d}_{6}\right): \delta 171.79,171.56,159.88$, $155.97,153.43,153.00,142.05,136.76,128.24$ (2C), 127.72, 127.62 (2C), 125.85, 115.16, 114.98, 112.20, 105.60, 65.53, 55.61, 38.18, 37.48, 31.67, 28.96, 23.11, 18.85, 18.13, 13.75. MS (EI): m/z 329 (65), 91 (65), 79 (100), 77 (73). Anal. $\left(\mathrm{C}_{28} \mathrm{H}_{33} \mathrm{~N}_{3} \mathrm{O}_{6}\right) \mathrm{C}, \mathrm{H}, \mathrm{N}$.

(S)-[1-(4-Methyl-2-oxo-2H-chromen-7-ylcarbamoyl)-5phenylacetylamino-pentyl]carbamic Acid Benzyl Ester (5d). Compound 5d was synthesized by method $C$ from $\mathbf{4 d}$ $(1.41 \mathrm{~g}, 3.54 \mathrm{mmol}), 2 \mathrm{a}(0.62 \mathrm{~g}, 3.54 \mathrm{mmol})$, and $\mathrm{POCl}_{3}(0.6$ $\mathrm{mL}$ ). The resulting product was chromatographed with ethyl acetate/methanol (10:1) and with dichloromethane/methanol (20:1). Yield: $0.37 \mathrm{~g}(19 \%) ; \mathrm{mp} 156^{\circ} \mathrm{C}$. IR: 3303, 2939, 1692, $1620,1584,1524 .{ }^{1} \mathrm{H} N M R\left(\mathrm{CDCl}_{3}\right): \delta 9.42(\mathrm{~s}, 1 \mathrm{H}), 7.64-7.19$ $(\mathrm{m}, 13 \mathrm{H}), 6.16(\mathrm{~s}, 1 \mathrm{H}), 5.88(\mathrm{~d}, 1 \mathrm{H}, 3 \mathrm{~J}=7.62 \mathrm{~Hz}), 5.78(\mathrm{t}, 1 \mathrm{H}$, 3) $=5.66 \mathrm{~Hz}), 5.12-5.11(\mathrm{~m}, 2 \mathrm{H}), 4.36-4.35(\mathrm{~m}, 1 \mathrm{H}), 3.54(\mathrm{~s}$, $1 \mathrm{H}), 3.24-3.16(\mathrm{~m}, 2 \mathrm{H}), 2.39(\mathrm{~s}, 3 \mathrm{H}), 1.94-1.38(\mathrm{~m}, 6 \mathrm{H}) .{ }^{13} \mathrm{C}$ NMR $\left(\mathrm{CDCl}_{3}\right): \delta 171.63,170.90,161.16,156.56,153.88$, $152.41,141.45,136.02,134.62,129.38(2 \mathrm{C}), 128.98$ (2C), $128.50,128.20$ (2C), $127.95(2 \mathrm{C}), 127.36,125.02,115.94$, $115.77,113.22,107.19,67.32,55.45,43.87,38.70,31.64,28.78$, 22.44, 18.80. MS (EI): m/z 91 (60), 79 (100), 77 (85). Anal. $\left(\mathrm{C}_{32} \mathrm{H}_{33} \mathrm{~N}_{3} \mathrm{O}_{6}\right) \mathrm{C}, \mathrm{H}, \mathrm{N}$. 
(S)-[1-(4-Methyl-2-oxo-2H-chromen-7-ylcarbamoyl)-5(2,2,2-trifluoroacetylamino)pentyl]carbamic Acid Benzyl Ester (5e). Compound $\mathbf{5 e}$ was synthesized by method $\mathrm{C}$ from 4 e $(0.64 \mathrm{~g}, 1.7 \mathrm{mmol}), 2 \mathrm{a}(0.30 \mathrm{~g}, 1.7 \mathrm{mmol})$, and $\mathrm{POCl}_{3}$ $(0.25 \mathrm{~mL})$. The resulting product was chromatographed with ethyl acetate/n-hexane (2:3) and with tetrahydrofuran/nhexane (1:1). Yield: $0.16 \mathrm{~g}$ (18\%); mp ${ }^{\circ} \mathrm{C}$. IR: 3309, 3095, 2947, 1705, 1620, 1584, 1528, 1182. ${ }^{1} \mathrm{H}$ NMR (DMSO-d 6 ): $\delta 10.47$ $(\mathrm{s}, 1 \mathrm{H}), 9.39(\mathrm{~s}, 1 \mathrm{H}), 7.75-7.29(\mathrm{~m}, 9 \mathrm{H}), 6.23(\mathrm{~s}, 1 \mathrm{H}), 5.01(\mathrm{~s}$, $2 \mathrm{H}), 4.13-4.10(\mathrm{~m}, 1 \mathrm{H}), 3.15-3.14(\mathrm{~m}, 2 \mathrm{H}), 2.38(\mathrm{~s}, 3 \mathrm{H}), 1.66-$ $1.31(\mathrm{~m}, 6 \mathrm{H}) .{ }^{13} \mathrm{C} N M R\left(\mathrm{DMSO}-\mathrm{d}_{6}\right): \delta 171.69,159.86,155.97$, $155.96\left(\mathrm{q}, \mathrm{2}_{\mathrm{C}, \mathrm{F}}=35.1 \mathrm{~Hz}\right), 153.43,152.90,142.02,136.73$, 128.20 (2C), 127.68, 127.59 (2C), 125.76, 115.15, 114.97, 113.59 $(q$, IJ $c, F=278.5 \mathrm{~Hz}), 112.21,105.62,65.53,55.51,39.71,31.28$, 28.03, 22.99, 18.13. MS (EI): m/z 271 (59), 180 (59), 175 (58), 91 (100), 79 (78), 77 (64). Purity was only 90\%, tested by HPLC (two methods, UV detection).

(R)-6-Acetylamino-2-benzyloxycarbonylamino-hexanoic Acid (6). Compound $\mathbf{6}$ was synthesized by method B from $\mathrm{N}$ - $\alpha$-benzyloxycarbonyl-D-lysine (Z-D-Lys) ( $1 \mathrm{~g}, 3.57 \mathrm{mmol}$ ) and acetic anhydride $(0.34 \mathrm{~mL}, 3.57 \mathrm{mmol})$. Yield: $1.00 \mathrm{~g}(87 \%)$, viscous oil.

(R)-[5-Acetylamino-1-(4-methyl-2-oxo-2H-chromen-7ylcarbamoyl)pentyl]carbamic Acid Benzyl Ester (7). Compound 7 was synthesized by method C from 6 (0.94 g, 2.9 $\mathrm{mmol}), 2 \mathrm{a}(0.51 \mathrm{~g}, 2.9 \mathrm{mmol})$, and $\mathrm{POCl}_{3}(0.5 \mathrm{~mL})$. The resulting product was chromatographed with ethyl acetate. Yield: $0.63 \mathrm{~g}(45 \%) ; \mathrm{mp} 147^{\circ} \mathrm{C}$. IR: 3309, 2934, 2863, 1692, 1526. ${ }^{1} \mathrm{H}$ NMR (DMSO-d 6 ): $\delta 10.19(\mathrm{~s}, 1 \mathrm{H}), 7.70\left(\mathrm{~d}, 1 \mathrm{H},{ }^{4} \mathrm{~J}=\right.$ $1.76 \mathrm{~Hz}), 7.61(\mathrm{~m}, 1 \mathrm{H}), 7.50 \mathrm{~d}, 1 \mathrm{H}, 3 \mathrm{~J}=8.60 \mathrm{~Hz}), 7.42(\mathrm{dd}$, $\left.1 \mathrm{H}, 3 \mathrm{~J}=8.79 \mathrm{~Hz},{ }^{4} \mathrm{~J}=1.76 \mathrm{~Hz}\right), 7.26(\mathrm{~d}, 1 \mathrm{H}, 3 \mathrm{~J}=7.82 \mathrm{~Hz})$, $7.14(\mathrm{~m}, 5 \mathrm{H}), 6.18(\mathrm{~s}, 1 \mathrm{H}), 5.07-4.88(\mathrm{~m}, 2 \mathrm{H}), 4.24-4.06(\mathrm{~m}$, $1 \mathrm{H}), 3.11-2.84(\mathrm{~m}, 2 \mathrm{H}), 2.32(\mathrm{~s}, 3 \mathrm{H}), 1.98(\mathrm{~s}, 3 \mathrm{H}), 1.79-1.38$ $(\mathrm{m}, 6 \mathrm{H}) .{ }^{13} \mathrm{C}$ NMR (DMSO- $\left.\mathrm{d}_{6}\right): \delta 171.38,168.93,159.74$, $155.73,153.31,152.12,141.86,136.35,127.84(2 \mathrm{C}), 127.35$ (2C) $127.31,124.89,115.94,114.75,112.07,105.78,65.50$, $55.42,38.21,31.37,28.61,22.83,22.52,18.07 . \mathrm{MS}(\mathrm{EI}): \mathrm{m} / \mathrm{z}$ 126 (77), 91 (71), 84 (60), 79 (100), 77 (74). Anal. $\left(\mathrm{C}_{26} \mathrm{H}_{29} \mathrm{~N}_{3} \mathrm{O}_{6}\right)$ C, $\mathrm{H}, \mathrm{N}$

(S)-\{4-Boc-amino-1-[(4-methyl-2-oxo-2H-chromen-7ylcarbamoyl)methyl]butyl\} carbamic Acid Benzyl Ester (9). Compound 9 was synthesized by method $D$ from $N-\alpha-$ benzyloxycarbonyl-N- $\epsilon$-(Boc)- $\beta$-lysine (8) $(1.0 \mathrm{~g}, 2.63 \mathrm{mmol}), 2 \mathrm{2a}$ $(0.42 \mathrm{~g}, 2.63 \mathrm{mmol})$, isobutyl chloroformate $(0.31 \mathrm{~mL}, 2.4$ $\mathrm{mmol})$, and NMM $(0.69 \mathrm{~mL}, 7.2 \mathrm{mmol})$. The product was chromatographed with ethyl acetate/n-hexane (2:1). Yield: $0.40 \mathrm{~g} \mathrm{(31 \% );} \mathrm{mp} 129^{\circ} \mathrm{C}$. IR: 3330, 2977, 1734, 1620, 1582, 1514, 1393, 1368, 1169. ${ }^{1} \mathrm{H}$ NMR $\left(\mathrm{CDCl}_{3}\right): \delta 9.13(\mathrm{~s}, 1 \mathrm{H}), 7.79$ $(\mathrm{d}, 1 \mathrm{H}, 3 \mathrm{~J}=8.29 \mathrm{~Hz}), 7.59(\mathrm{~s}, 1 \mathrm{H}), 7.49(\mathrm{~d}, 1 \mathrm{H}, 3 \mathrm{~J}=8.77 \mathrm{~Hz})$, 7.26-7.23 (s, 5H), $6.18(\mathrm{~s}, 1 \mathrm{H}), 5.78(\mathrm{~d}, 1 \mathrm{H}, 3 \mathrm{~J}=8.53 \mathrm{~Hz}), 5.05$ $(\mathrm{s}, 2 \mathrm{H}), 4.77(\mathrm{~s}, 1 \mathrm{H}), 4.09-4.08(\mathrm{~m}, 1 \mathrm{H}), 3.12(\mathrm{~m}, 1 \mathrm{H}), 2.68(\mathrm{~d}$, $1 \mathrm{H}, 3 \mathrm{~J}=5.12 \mathrm{~Hz}), 2.40(\mathrm{~s}, 3 \mathrm{H}), 1.95-1.26(\mathrm{~m}, 13 \mathrm{H}) .{ }^{13} \mathrm{C} \mathrm{NMR}$ $\left(\mathrm{CDCl}_{3}\right)$ : $\delta 170.15,161.72,156.50,156.33,153.99(2 \mathrm{C}), 142.12$, 136.50, 128.59 (2C), 128.18, 128.01 (2C), 125.46, 116.17. $116.06,113.15,107.04,79.55,67.01,49.06,42.74,40.46,32.39$, 28.81, 27.21, 19.07. MS (EI): m/z 437 (30), 307 (43), 286 (46), 285 (45), 263 (49) 175 (90), 91 (100), 79 (78), 77 (47).

(S)-\{4-Acetylamino-1-[(4-methyl-2-oxo-2H-chromen-7ylcarbamoyl)methyl]butyl \} carbamic Acid Benzyl Ester (10). Compound $9(0.32 \mathrm{~g}, 0.60 \mathrm{mmol})$ was dissolved in a mixture of trifluoroacetic acid in dichloromethane (1:1, $4 \mathrm{~mL})$. After the mixture was stirred for $10 \mathrm{~min}$, methanol was added, and the solvents were evaporated. This step was repeated until the smell of trifluoroacetic acid had disappeared. The resulting amine was treated without further workup with acetic anhydride ( 1 equiv) in pyridine, according to method $B$. The product was precipitated after evaporation and redissolution in tetrahydrofuran with n-hexane. Yield: $0.26 \mathrm{~g}(93 \%) ; \mathrm{mp} 198{ }^{\circ} \mathrm{C}$. IR: 3302, 1731, 1690, 1622, 1524. ${ }^{1} \mathrm{H}$ NMR (DMSO-d 6 ): $\delta$ $10.33(\mathrm{~s}, 1 \mathrm{H}), 7.79(\mathrm{t}, 1 \mathrm{H}, 3 \mathrm{~J}=5.27 \mathrm{~Hz}), 7.72(\mathrm{~d}, 1 \mathrm{H}, 4 \mathrm{~J}=1.95$ $\mathrm{Hz}), 7.67(\mathrm{~d}, 1 \mathrm{H}, 3 \mathrm{~J}=8.6 \mathrm{~Hz}), 7.43(\mathrm{dd}, 3 \mathrm{~J}=8.79 \mathrm{~Hz}, 4 \mathrm{~J}=$ $1.76 \mathrm{~Hz}), 7.32-7.24(\mathrm{~m}, 5 \mathrm{H}), 6.23(\mathrm{~s}, 1 \mathrm{H}), 5.00-4.96(\mathrm{~m}, 2 \mathrm{H})$, $3.37(\mathrm{~m}, 1 \mathrm{H}), 2.97-2.95(\mathrm{~m}, 2 \mathrm{H}), 2.52-2.47(\mathrm{~m}, 5 \mathrm{H}), 1.75(\mathrm{~s}$, $3 \mathrm{H}),{ }_{1.68}-1.14(\mathrm{~m}, 4 \mathrm{H}) .{ }^{13} \mathrm{C}$ NMR $\left(\mathrm{DMSO}^{\left.-\mathrm{d}_{6}\right): \delta} 169.48\right.$,
$168.59,159.77,155.34,153.38,152.87,142.24,137.01,128.08$ (2C), 127.46, $127.33(2 \mathrm{C}), 125.67,114.98,114.70111 .99$, $105.40,64.94,48.03,42.44,31.88,25.99,22.65,18.05$. MS (EI): $\mathrm{m} / \mathrm{z} 95$ (24), 91 (17), 79 (100), 74 (58). The purity was more than 99\%, tested by HPLC (two methods, UV detection).

(S)-[5-Acetylamino-1-(4-methyl-2-oxo-2H-chromen-7ylcarbamoyl)pentyl]carbamic Acid 9H-Fluoren-9-ylmethyl Ester (12a). Compound 12a was synthesized by method C from $\mathrm{N}$ - $\alpha$-(9-fluorenylmethoxycarbonyl)- $\mathrm{N}$ - $\epsilon$-acetyl-lysine (11a) $(0.50 \mathrm{~g}, 1.22 \mathrm{mmol}), 2 \mathrm{a}(0.21 \mathrm{~g}, 1.22 \mathrm{mmol})$, and $\mathrm{POCl}_{3}(0.25$ $\mathrm{mL})$. The resulting product was chromatographed with ethyl acetate/methanol (10:1). Yield: $0.17 \mathrm{~g} \mathrm{(25 \% );} \mathrm{mp} 197^{\circ} \mathrm{C}$. IR: $3282,1734,1664,1623,1526 .{ }^{1} \mathrm{H}$ NMR (DMSO-d 6 ): $\delta 10.48$ $(\mathrm{s}, 1 \mathrm{H}), 7.88-7.30(\mathrm{~m}, 13 \mathrm{H}), 6.25(\mathrm{~s}, 1 \mathrm{H}), 4.28-4.23(\mathrm{~m}, 4 \mathrm{H})$, 3.00-2.99 (m, 2H), $2.39(\mathrm{~s}, 3 \mathrm{H}), 1.75(\mathrm{~s}, 3 \mathrm{H}), 1.70-1.39(\mathrm{~m}$, $6 \mathrm{H}) .{ }^{13} \mathrm{C}$ NMR (DMSO-d 6 ): $\delta 171.73,168.62,159.75,155.87$, 153.38, 152.86, 143.53 (2C), 142.00, 140.47 (2C), 127.45 (2C), $126.86,125.78,125.12(2 \mathrm{C}), 119.94(2 \mathrm{C}), 115.05,114.90,112.13$ (2C), 105.51, 65.62, 55.42, 46.62, 38.29, 31.30, 28.90, 23.18, 22.66, 18.05. MS (EI): m/z 178 (100), 176 (22), 152 (16). The purity was more than $99 \%$, tested by H PLC (two methods, UV detection).

(S)-[5-Bocamino-1-(4-methyl-2-oxo-2H-chromen-7-ylcarbamoyl)pentyl]carbamic Acid 9H-Fluoren-9-ylmethyl Ester (12b). Compound 12b was synthesized by method $C$ from $\mathrm{N}$ - $\alpha$-(9-fluorenylmethoxycarbonyl)-N- - -(tert-butyloxy-carbonyl)lysine ( $\alpha-F$ moc- $\left.\epsilon-\mathrm{O}^{\mathrm{t}} \mathrm{Bu}-\mathrm{L} y \mathrm{~s}, \mathbf{1 1 b}\right)(0.50 \mathrm{~g}, 1.07 \mathrm{mmol}$ ), 2a $(0.19 \mathrm{~g}, 1.07 \mathrm{mmol})$, and $\mathrm{POCl}_{3}(0.2 \mathrm{~mL})$. The resulting product was chromatographed with ethyl acetate/n-hexane (3:2). Yield: $0.20 \mathrm{~g} \mathrm{(30 \% );} \mathrm{mp} 180{ }^{\circ} \mathrm{C}$. The purity was more than $99 \%$, tested by HPLC (two methods, UV detection).

(R,S)-4-[2-(9H-Fluoren-9-ylmethoxycarbonyl)-2-(4-methyl-2-oxo-2H-chromen-7-ylcarbamoyl)ethyl]piperidine-1carboxylic Acid tert-Butyl Ester (14). Compound 14 was synthesized by method D from $\mathrm{N}-\alpha$-(9-fluorenylmethoxyxarbonyl)- $\beta$-(1-butyloxycarbonyl-pi perine-4-yl)-D,L-al anine (13) $(0.50$ $\mathrm{g}, 1 \mathrm{mmol}), 2 \mathrm{a}(0.18 \mathrm{~g}, 1 \mathrm{mmol}), \mathrm{NMM}(0.33 \mathrm{~mL}, 3 \mathrm{mmol})$, and isobutyl chloroformate $(0.13 \mathrm{~mL}, 1 \mathrm{mmol})$. The resulting product was chromatographed with ethyl acetate/n-hexane (1: 1). Yield: $0.17 \mathrm{~g}(26 \%) ; \mathrm{mp} 140{ }^{\circ} \mathrm{C}$. The purity was more than 99\%, tested by HPLC (two methods, UV detection).

HDAC Assays. Rat Liver Enzyme. Rat liver HDAC was purified by ammonium sulfate precipitation and chromatography on Q-sepharose with an increasing gradient of sodium chloride, as described. ${ }^{9}$ This preparation is al so commercially available (EMD Biosciences, Alexis).

HPLC Assay. For the inhibition assay, the standard substrate was $\mathbf{3 a}$. For conversion assays, the different compounds were used as substrates, and an internal standard, 7-hydroxycoumarin, was included for quantitation purposes. The HPLC assay was performed on the LiChrosorb column with acetonitrile/water $(40 / 60 \mathrm{v} / \mathrm{v})$ as the mobile phase at a flow rate of $0.6 \mathrm{~mL} / \mathrm{min}$. The excitation wavelength was 330 $\mathrm{nm}$ (340 nm for 3b), and the emission wavelength was 390 $\mathrm{nm}$ (430 nm for 3b). The retention times were 4.05 (3a), 10.26 (3b), 5.43 (5a), 6.87 (5b), 9.42 (5c), 18.93 (5d), 12.68 (5e), 5.43 (7), and 20.10 (12a) min. To determine $\mathbf{1 2 b}$ and $\mathbf{1 4}$, we used a Luna $5 \mu \mathrm{m}$ Phenylhexyl column with methanol/water (90/10 $\mathrm{v} / \mathrm{v})$ as the mobile phase at a flow rate of $0.7 \mathrm{~mL} / \mathrm{min}$. The excitation wavelength was $330 \mathrm{~nm}$, and the emission wave length was $390 \mathrm{~nm}$. Retention times were 9.95 (12b) and 12.70 (14) min. Results are from at least duplicate determinations. To determine the resulting metabolites, we used a Luna $5 \mu \mathrm{m}$ Phenylhexyl column with acetonitrile/water/trifluoroacetic acid $(55 / 45 / 0.01 \mathrm{v} / \mathrm{v} / \mathrm{v})$ as the mobile phase at a flow rate of $0.5 \mathrm{~mL} /$ $\mathrm{min}$. The retention times were $4.01 \mathrm{~min}$ for the metabolite of 3a, $5.05 \mathrm{~min}$ for the metabolite of $\mathbf{3 b}, 3.99 \mathrm{~min}$ for the metabolites of $\mathbf{5 a}-\mathbf{c}, \mathbf{e}$ and $\mathbf{7}$, and $5.40 \mathrm{~min}$ for the metabolite of 12a. Stock solutions of compounds were made at $12.6 \mathrm{mM}$ in DMSO (3b, 5a, c-e 7, 10, and 12a), $12.6 \mathrm{mM}$ in ethanol (3a), or $12 \mathrm{mM}$ in DMSO (5b, $\mathbf{1 2} \mathbf{b}$, and $\mathbf{1 4})$ and further diluted with enzyme buffer [1.4 mM NaH${ }_{2} \mathrm{PO}_{4}, 18.6 \mathrm{mM} \mathrm{Na} \mathrm{HPO}_{4}$, pH 7.9, $0.25 \mathrm{mM}$ EDTA, $10 \mathrm{mM} \mathrm{NaCl}, 10 \%$ (v/v) glycerol, and $10 \mathrm{mM}$ 2-mercaptoethanol]. A stock solution was prepared 
using an aliquot of $10 \mu \mathrm{L}$ of the substrate (3a or compound to test), $15 \mu \mathrm{L}$ of a solution of the standard 7-hydroxycoumarin in DMSO $(6.3 \mathrm{mg} / \mathrm{mL})$, and enzyme buffer to a total vol ume of $1 \mathrm{~mL}$. For inhibitor screening, the stock solution of the compound [12.6 mM in DMSO for $\mathbf{3 b}, \mathbf{5 a}, \mathbf{c}-\mathbf{e}, \mathbf{7}, \mathbf{1 0}$, and $\mathbf{1 2 a}$; $12 \mathrm{mM}$ in DMSO for 5b, 12b, 14 and MD85 (16a); $3.3 \mathrm{mM}$ in DMSO for TSA (15)] was diluted with enzyme buffer in such a fashion that a concentration was obtained that was 12-fold higher than the highest test concentration desired in the assay.

The substrate/standard stock solution $(10 \mu \mathrm{L})$ was added to a mixture of $100 \mu \mathrm{L}$ of rat enzyme preparation (at $4{ }^{\circ} \mathrm{C}$ ) and $10 \mu \mathrm{L}$ of buffer or inhibitor solution. After $15 \mathrm{~min}$ at $4^{\circ} \mathrm{C}$, the mixture was incubated at $37{ }^{\circ} \mathrm{C}$ for the desired time. The reaction was stopped by adding $72 \mu \mathrm{L}$ of $1 \mathrm{M} \mathrm{HCl} / 0.4 \mathrm{M}$ sodium acetate and $800 \mu \mathrm{L}$ of ethyl acetate, and the mixture was centrifuged at $10000 \mathrm{rpm}$ for $5 \mathrm{~min}$. An aliquot $(200 \mu \mathrm{L})$ of the upper phase was taken, and the solvent was removed with a stream of nitrogen. The residue was dissolved in $600 \mu \mathrm{L}$ of chromatography eluent, and $20 \mu \mathrm{L}$ was injected by the autosampler onto the HPLC system. The amount of remaining substrate was calculated relative to the substrate control without enzyme as the quotient of the peak area of the substrate divided by the peak area of the internal standard. F or the determination of the metabolites, the incubation was stopped by adding $1 \mathrm{~mL}$ of acetonitrile instead of $72 \mu \mathrm{L}$ of $1 \mathrm{M}$ $\mathrm{HCl} / 0.4 \mathrm{M}$ sodium acetate, and the mixture was centrifuged as above. The supernatant was removed, and $20 \mu \mathrm{L}$ was injected by autosampler onto the HPLC system.

hSIRT1 Incubation and O-Acetyl ADP Ribose Detection. To assess reactivity with hSIRT1, we used a different enzyme buffer (25 mM Tris- $\mathrm{HCl}, \mathrm{pH}$ 8.0, $137 \mathrm{mM} \mathrm{NaCl}, 2.7$ $\mathrm{mM} \mathrm{KCl}$, and $1 \mathrm{mM} \mathrm{MgCl}_{2}$ ) for all dilutions and incubations. The substrate solutions were prepared as described with stock solutions of $\mathbf{3 a}, \mathbf{b}, \mathbf{5} \mathbf{a}-\mathbf{d}$, and the internal standard 7-hydroxycoumarin. A NAD ${ }^{+}$stock solution $(6 \mathrm{mM})$ was prepared in water. The substrate solution $(5 \mu \mathrm{L})$ was mixed with $2.5 \mu \mathrm{L}$ of hSIRT1, $5 \mu \mathrm{L}$ of the NAD ${ }^{+}$solution, and enzyme incubation buffer to a total volume of $60 \mu \mathrm{L}$. The incubation at $37^{\circ} \mathrm{C}$ was stopped after $16 \mathrm{~h}$ by adding $36 \mu \mathrm{L}$ of $1 \mathrm{M} \mathrm{HCl} / 0.4 \mathrm{M}$ sodium acetate, extracted with $400 \mu \mathrm{L}$ of ethyl acetate, and consecutively treated as described above. For mass spectroscopy analysis, the reaction mixtures ( $60 \mu \mathrm{L}$ total volume) contained $500 \mu \mathrm{M}$ of the substrate, $300 \mu \mathrm{M} \mathrm{NAD}^{+}, 1 \mathrm{mM}$ dithiothreitol, $20 \mathrm{mM}$ pyridine, and $1 \mathrm{mM} \mathrm{MgCl}$. In the positive ion mode in the ESI spectrum, the peak for O-acetyl ADP-ribose can be found at 602 . MS/MS analysis of this peak led to fragments $(M+1)$, such as adenosine diphosphate (428), adenosine monophosphate (349), O-acetyl ribose monophosphate (274), ribose monophosphate (232), and adenine (132) (see Supporting I nformation; peaks were assigned as described ${ }^{33}$ ).

Homogeneous Assay, Recombinant HDACs. The homogeneous assay was performed as reported. ${ }^{10}$ Aliquots $(10 \mu \mathrm{L})$ of stock solutions of $\mathbf{3 a}, \mathbf{b}$ and $\mathbf{5 b}$ (12.6 mM in DMSO) were diluted in enzyme buffer [1.4 $\mathrm{mM} \mathrm{NaH}{ }_{2} \mathrm{PO}_{4}, 18.6 \mathrm{mM} \mathrm{Na}$ N $^{-}$ $\mathrm{HPO}_{4}, \mathrm{pH} 7.9,0.25 \mathrm{mM}$ EDTA, $10 \mathrm{mM} \mathrm{NaCl}, 10 \%(\mathrm{v} / \mathrm{v})$ glycerol, and $10 \mathrm{mM}$ 2-mercaptoethanol] to a total vol ume of $1 \mathrm{~mL}$ and used as substrate solutions. I mmunoprecipitated human FLAG-tagged HDAC1, HDAC3, and HDAC 6 ${ }^{34,35}$ were prepared as described. M2 agarose (Sigma) was used at $25 \mu \mathrm{L} /$ $\mathrm{mL}$ lysate. Lysates of wild-type 293T cells served as a control. The immunoprecipitated enzymes were washed in enzyme buffer and used as the enzyme source. M2 agarose beads ( 2.5 $\mu \mathrm{L})$ with precipitated enzymes were resuspended in $47.5 \mu \mathrm{L}$ of buffer and mixed with $10 \mu \mathrm{L}$ of buffer as blank. Five microliters of the substrate solution and $5 \mu \mathrm{L}$ of the buffer were added instead of $10 \mu \mathrm{L}$ of buffer to measure a negative control (no inhibition), respectively. Five microliters of the substrate solution and $5 \mu \mathrm{L}$ of TSA solution $(3.3 \mu \mathrm{M})$ were added to measure a positive control (100\% inhibition). These mixtures were incubated at $37^{\circ} \mathrm{C}$ for $180 \mathrm{~min}$ (300 min for the immunoprecipitated HDAC3). The reaction was stopped by adding $190 \mu \mathrm{L}$ of freshly prepared mixture of TSA $(3.3 \mu \mathrm{M}$ in enzyme buffer), borate buffer $(0.1 \mathrm{mM}$ boric acid, adjusted with $1 \mathrm{M} \mathrm{NaOH}$ to $\mathrm{pH}$ 9.5), and naphthalene-2,3-dicarboxaldehyde
(16 $\mathrm{mM}$ in methanol) in a ratio of 5/180/5 (v/v/v). The fluorescence was measured at $330 / 390 \mathrm{~nm}$. The amount of substrate remaining in the samples containing the enzyme was calculated relative to the amount of substrate in the positive control (TSA) sample.

Inhibitor Selectivity. The subtype sel ectivity of inhibitors $\mathbf{1 6 b}, \mathbf{c}$ was determined with a radioactive peptidic substrate as described. ${ }^{34}$ Selectivity screening was performed with the inhibitors CHAP1 (17a), CHAP15 (17b), and CHAP31 (17c) at final concentrations of $830,280,83,28,8.3$, and $2.8 \mathrm{nM}$ and with M344 (16b) and M360 (16c) at final concentrations of $10,3.3,1,0.33,0.1$, and $0.033 \mu \mathrm{M}$ and $\mathbf{3 a}, \mathbf{b}$ and $\mathbf{5 b}$ as substrates in the homogeneous assay. The rat liver enzyme (50 $\mu \mathrm{L}$, prepared as described ${ }^{10}$ but with phosphate buffer instead of Tris) was mixed with $10 \mu \mathrm{L}$ of the buffer as blank, with $5 \mu \mathrm{L}$ of the substrate solution and $5 \mu \mathrm{L}$ of the buffer as negative control and with $5 \mu \mathrm{L}$ of the substrate solution and 5 $\mu \mathrm{L}$ of the positive control solution (3.3 $\mu \mathrm{M}$ TSA) as a positive control. Samples were prepared by mixing $50 \mu \mathrm{L}$ of the enzyme solution with $5 \mu \mathrm{L}$ of each inhibitor solution and $5 \mu \mathrm{L}$ of the substrate solution. These mixtures were incubated at $37{ }^{\circ} \mathrm{C}$ for 90 (3a) and 180 ( $\mathbf{3 b}$ and $\mathbf{5 b}$ ) $\mathrm{min}$. The reaction was stopped and analyzed as described above. The amount of remaining substrate in the positive control with TSA was calculated relative to the negative control without enzyme to give the $100 \%$ value. Partial conversion is related to that value.

Acknowledgment. Funding by Circagen Pharmaceuticals is gratefully acknowledged by B.H. and M.J . Very hel pful suggestions for the modified sirtuin buffer were made by Drs. M. D. J ackson and J. M. Denu, Oregon Science and Health University. We thank Dr. H. Luftmann, University of Münster, for measuring the ESI mass spectra for the detection of O-acetyl ADPribose.

Supporting I nformation Available: Additional spectral data for compounds $\mathbf{4 b}-\mathbf{d}, \mathbf{6}, \mathbf{1 2} \mathbf{b}$, and $\mathbf{1 4}$, mass spectra of O-acetyl ADP ribose, and information on compound purity with HPLC and elemental analysis data. This material is available free of charge via the Internet at http://pubs.acs.org.

\section{References}

(1) Grozinger, C. M.; Schreiber, S. L. Deacetylase enzymes: Biological functions and the use of small-molecule inhibitors. Chem. Biol. 2002, 9, 3-16.

(2) J ohnstone, R. W. Histone-deacetylase inhibitors: novel drugs for the treatment of cancer. Nat. Rev. Drug Discovery 2002, 1, 287-299.

(3) Gray, S. G.; Ekstrom, T. J . The human histone deacetylase family. Exp. Cell Res. 2001, 262, 75-83.

(4) Finnin, M.S.; Donigian, J . R.; Cohen, A.; Richon, V. M.; Rifkind R. A.; et al. Structures of a histone deacetylase homologue bound to the TSA and SAHA inhibitors. Nature 1999, 401, 188-193.

(5) Remiszewski, S. W.; Sambuccetti, L. C.; Atadja, P.; Bair, K. W.; Cornell, W. D.; et al. Inhibitors of human histone deacetylase: synthesis, enzyme and cellular activity of straight chain hydroxamates. J . Med. Chem. 2002, 45, 753-757.

(6) Wegener, D.; Hildmann, C.; Riester, D.; Schwienhorst, A. Improved fluorogenic histone deacetylase assay for highthroughput screening applications. Anal. Biochem. 2003, 321, 202-208.

(7) Wegener, D.; Wirsching, F.; Riester, D.; Schwienhorst, A. A fluorogenic histone deacetylase assay well suited for highthroughput activity screening. Chem. Biol. 2003, 10, 61-68.

(8) H offmann, K.; Brosch, G.; Loidl, P.; J ung, M. A nonisotopic assay for histone deacetylase activity. Nucleic Acids Res. 1999, 27, 2057-2058.

(9) Heltweg, B.; J ung, M. A micro plate reader based nonisotopic histone deacetylase activity assay. Anal. Biochem. 2002, 302, 175-183.

(10) Heltweg, B.; J ung, M. A homogeneous nonisotopic assay for histone deacetylase activity. J . Biomol. Screening 2003, 8, 8995.

(11) Heltweg, B.; Dequidt, F.; Verdin, E.; J ung, M. A nonisotopic substrate for assaying both human zinc and $\mathrm{NAD}^{+}$-dependent histone deacetylases. Anal. Biochem. 2003, 319, 42-48. 
(12) Rijkers, D. T. S.; Adams, H. P. H. M.; Hemker, H. C.; Tesser, G. I. A convenient synthesis of amino acid p-nitroanilides- synthons in the synthesis of protease substrates. Tetrahedron 1995, 51, $11235-11250$.

(13) Bernardi, L.; De Castiglione, R.; Fregnan, G. B.; Glässer, A. H An experimental approach to long-lasting hypotensive el edoisinlike peptides. J . Pharm. Pharmacol. 1967, 19, 95-101.

(14) Hoffmann, K.; Heltweg, B.; J ung, M. I mprovement and validation of the fluorescence-based histone deacetylase assay using an internal standard. Arch. Pharm. Pharm. Med. Chem. 2001, $334,248-252$

(15) J ackson, M. D.; Schmidt, M. T.; Oppenheimer, N.J .; Denu, J . M. Mechanism of nicotinamide inhibition and transglycosidation by Sir2 histone/protein deacetylases. J . Biol. Chem. 2003, 278, 50985-50998.

(16) Fischle, W.; Dequiedt, F.; Fillion, M.; Hendzel, M. J .; Voelter, W.; et al. Human HDAC7 histone deacetylase activity is associated with HDAC3 in vivo. J. Biol. Chem. 2001, 20, 35826-35835.

(17) J ung, M.; Brosch, G.; Kölle, D.; Scherf, H.; Gerhäuser, C.; et al Amide analogues of trichostatin A as inhibitors of histone deacetylase and inducers of terminal cell differentiation. J . Med. Chem. 1999, 42, 4669-4679.

(18) Furumai, R.; Komatsu, Y.; Nishino, N.; Khochbin, S.; Yoshida M.: et al. Potent histone deacetylase inhibitors built from trichostatin A and cyclic tetrapeptide antibiotics including trapoxin. Proc. Natl. Acad. Sci. U.S.A. 2001, 98, 87-92.

(19) Yoshida, M.; Furumai, R.; Komatsu, Y.; Nishino, N.; Horinouchi, $\mathrm{S}$. Histone deacetylase as a new target for cancer chemotherapy. Cancer Chemother. Pharmacol. 2001, 48 (Suppl. 1), S20-S26.

(20) Wang, D. F.; Wiest, O.; Helquist, P.; Lan-Hargest, H. Y.; Wiech, N. L. On the function of the $14 \mathrm{~A}$ long internal cavity of histone deacetylase-like protein: I mplications for the design of histone deacetylase inhibitors. J . Med. Chem. 2004, 47, 3409-3417.

(21) Bouchain, G.; Delorme, D. Novel hydroxamate and anilide derivatives as potent histone deacetylase inhibitors: Synthesis and antiproliferative evaluation. Curr. Med. Chem. 2003, 10, 2359-2372.

(22) J aboin, J.; Wild, J .; Hamidi, H.; Khanna, C.; Kim, C. J .; et al . MS-27-275, an inhibitor of histone deacetylase, has marked in vitro and in vivo antitumor activity against pediatric solid tumors. Cancer Res. 2002, 62, 6108-6115.

(23) Saito, A.: Yamashita, T. Mariko, Y. Nosaka, Y.: Tsuchiya, K. et al. A synthetic inhibitor of histone deacetylase, MS-27-275, with marked in vivo antitumor activity against human tumors. Proc. Natl. Acad. Sci. U.S.A. 1999, 96, 4592-4597.
(24) Suzuki, T.; Ando, T.; Tsuchiya, K.; Fukazawa, N.; Saito, A.; et al. Synthesis and histone deacetylase inhibitory activity of new benzamide derivatives. J . Med. Chem. 1999, 42, 3001-3003.

(25) Wong, J. C.; Hong, R.; Schreiber, S. L. Structural biasing elements for in-cell histone deacetylase paralog selectivity. J. Am. Chem. Soc. 2003, 125, 5586-5587.

(26) Fournel, M.; Trachy-Bourget, M. C.; Yan, P. T.; Kalita, A.; Bonfils, C.; et al. Sulfonamide anilides, a novel class of histone deacetylase inhibitors, are antiproliferative against human tumors. Cancer Res. 2002, 62, 4325-4330.

(27) Kraker, A. J .; Mizzen, C. A.; Hartl, B. G.; Miin, J .; Allis, C. D.; et al. Modulation of histone acetylation by [4-(acetylamino)- $\mathrm{N}$ (2-amino-phenyl) benzamide] in HCT-8 colon carcinoma. Mol. Cancer Ther. 2003, 2, 401-408.

(28) Haggarty, S. J.: Koeller, K. M.; Wong, J. C.; Grozinger, C. M. Schreiber, S. L. Domain-selective small-molecule inhibitor of histone deacetylase 6 (HDAC6)-mediated tubulin deacetylation. Proc. Natl. Acad. Sci. U.S.A. 2003, 100, 4389-4394.

(29) Cao, H.; Stamatoyannopoulos, G.; J ung, M. Induction of human gamma gl obin gene expression by histone deacetylase inhibitors. Blood 2004, 103, 701-709.

(30) H offmann, K.; Brosch, G.; Loidl, P.; J ung, M. First nonradioactive assay for in vitro screening of histone deacetylase inhibitors. Pharmazie 2000, 55, 601-606.

(31) J ung, M.; Hoffmann, K.; Brosch, G.; Loidl, P. Analogues of trichostatin A and trapoxin $B$ as histone deacetylase inhibitors. Bioorg. Med. Chem. Lett. 1997, 7, 1655-1658.

(32) Schmidt, K.; Gust, R.; J ung, M. I nhibitors of histone deacetylase suppress the growth of MCF-7 breast cancer cells. Arch. Pharm. Pharm. Med. Chem. 1999, 332, 353-357.

(33) J ackson, M. D.: Denu, J. M. Structural identification of 2'- and 3'-O-acetyl-ADP-ribose as novel metabolites derived from the Sir2 family of beta-NAD+-dependent histone/protein deacetylases. I. Biol. Chem. 2002, 277, 18535-18544.

(34) Fischle, W.; Emiliani, S.; Hendzel, M. J .; Nagase, T.; Nomura, $\mathrm{N}$.; et al. A new family of human histone deacetylases related to saccharomyces cerevisiae HDAlp. J . Biol. Chem. 1999, 274, $11713-11720$.

(35) Fischle, W.; Dequiedt, F .; Hendzel, M. J .; Guenther, M. G.; Lazar, M. A.; et al. Enzymatic activity associated with class II HDACs is dependent on a multiprotein complex containing HDAC3 and SMRT/N-CoR. Mol. Cell 2002, 9, 45-57.

J M0497592 